\title{
TAFAKKUR DALAM PERSPEKTIF AL-QUR'AN
}

\author{
Oleh \\ Desri Ari Enghariano \\ Dosen Fakultas Syariah dan Ilmu Hukum IAIN Padangsidimpuan \\ email : desriarienghariano@iain-padangsidimpuan.ac.id
}

\begin{abstract}
Abstrac
Thinking is one of human privileges compared to other of God. In the uslub of qur'an, the word of this thought is expressed in the term tafakkur. Other terms that have some similaraties with it are ta'ammul and tadabbur. Tafakkur activity or thinking well and deeply is the key to opening the door of divine light, the door of all knowledge, the beginning or basis for the vision of conscience and the path to ma'rifatullah, so that it reaches a good understanding of Allah SWT. The urgency of tafakkur for a muslim is a form of self-reflection so that he can become a servant who is always gratefull. Tafakkur is very much beneficial if done accordingly. However, tafakkur has limits, among them : they can not bear testimony about the substance of God, do not harm, and tafakkur should make us more confident to God.
\end{abstract}

Kata Kunci; Tafakkur, Dalam, Perspektif , dan Al-Qur'an

\section{A. Pendahuluan}

Manusia diciptakan dengan kemampuan berfikir. Sesungguhnya berfikir adalah salah satu keistimewaan manusia bila dibandingkan dengan makhluk ciptaan Allah yang lain. Menurut psikologi, "Thinking is a inferring process" (berfikir adalah proses menarik kesimpulan). ${ }^{1}$ Dalam istilah al-Qur'an aktifitas berfikir ini disebut dengan tafakkur. Kata ini sangat dalam maknanya, seperti yang dikatakan oleh Ibnu al-Qayyim al-Jauziyah bahwa tafakur merupakan cermin yang akan memperlihatkan kepada seseorang perihal kebaikan dan keburukannya. ${ }^{2}$ Setiap manusia sesungguhnya pasti pernah berfikir/bertafakkur. Setiap malam menjelang tidur, otak kita selalu dihinggapi berbagai macam bentuk informasi dan perilaku yang telah kita dapatkan dan kita lakukan sepanjang hari. Berputar-putarlah otak kita mengenai perilaku kita, apa saja yang telah kita lakukan pada siang hari itu. Kita juga kadangkala berfikir atau bertafakur mengenai alam ciptaan Allah yang begitu dahsyat ini.

\footnotetext{
${ }^{1}$ Abdul Rahman Saleh, Psikologi Suatu Pengantar dalam Perspektif Islam, (Jakarta : Kencana Media Group, 2005), hlm. 15

${ }^{2}$ Ibnu al-Qayyim al-Jauziyah, al-Fawa'id, (Cairo : Dar al-Rayyan Li al-Turas, 1987), hlm. 255
} 
Di dalam islam, berfikir yang mendalam (tafakkur) itu sangat dianjurkan sekali sebagai bentuk introspeksi diri kita. Bertafakkur tentang ciptaan Allah SWT atau tentang perbuatan yang telah kita lakukan selama ini merupakan ibadah mulia yang diserukan Islam.

\section{B. Defenisi Tafakkur}

Dalam memaparkan makna tafakkur, sebagaimana lazimnya sebuah kajian ilmiah, istilah ini akan ditinjau secara mendalam dari dua sudut kajian, yakni makna etimologi dan makna terminologi. Memahami makna tafakkur dari dua sudut kajian ini akan sangat membantu dalam memamahi ayat-ayat al-Qur'an yang berkaitan dengan persoalan tersebut.

a. Tafakkur Secara Etimologi

Secara etimologi (bahasa), istilah tafakkur berasal dari bahasa Arab, yaitu altafakkur (التفكر). Kataal-tafakkur berasal dari تفكر يتفكر تفكرا, artinya hal berfikir ${ }^{3}$ dan memikirkan. ${ }^{4}$ Pengertian yang substansinya sama dengan definisi di atas juga dikemukakan oleh S. Wojowasito dalam karyanya Kamus Lengkap Inggris Indonesia-Indonesia Inggris, yaitu meditation, ${ }^{5}$ yang dalam bahasa Indonesia disebut dengan kata meditasi, renungan, diam memikirkan sesuatu dalam-dalam. Dalam Islam, tafakkur didasarkan atas ayat-ayat al-Qur'an yang ditujukan kepada mereka yang diberi pengetahuan dan dituntut untuk merenungkan tanda-tanda (fenomena) alam.

b. Tafakkur Secara Terminologi

Makna terminologi dari kata al-tafakkur, menurut al-Jurjani adalah :

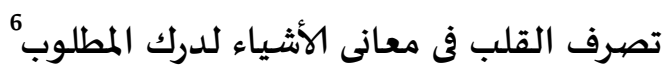

"Penggunaan (pengendalian) atas hati dalam rangka mencerna hakikat yang sebenarnya segala hal, demi menggapai maksud yang diinginkan"

Menurut penuturun Imam al-Ghazali, sebagaimana yang tercantum dalam karya besarnya Ihya' Ulumuddin, bahwa yang dimaksud dengan tafakkur adalah : hlm. 324

${ }^{3}$ Mahmud Yunus, Kamus Arab Indonesia, (Jakarta : PT. Mahmud Yunus Wa Dzurriyyah, 2010),

${ }^{4}$ Majamma' al-Lughah al-Arabiyah, al-Mu'jam al-Wasith, (Cairo : Maktabah al-Syuruq alArabiyyah, 2005), hlm. 698. Lihat juga : Atabik Ali, dkk, Kamus Kontemporer Arab Indonesia, (Yokyakarta : Multi Karya Grafika, 1998), hlm. 534

${ }^{5}$ S. Wojowasito, dkk, Kamus Lengkap Inggris Indonesia-Indonesia Inggris, (Bandung : HASTA Penerbit, 1983), hlm. 270

${ }^{6}$ Al-Jurjani, al-Ta'rifat, (Beirut : Dar al-Kutub al-Ilmiyyah, 1403 H), hlm. 66 
7 7 التفى التفر

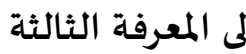

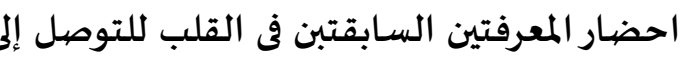

"Suatu upaya mendatangkan dua ma'rifat (yang bersemayam di sanubari) agar sampai kepada ma'rifat yang ketiga"

Sebagai penjelasannya, Imam al-Ghazali mencontohkan dengan seseorang yang mana tindak tanduknya lebih mementingkan kehidupan dunia yang fana ini ,kemudian dia ingin tahu bahwasanya kehidupan akhirat yang kekal jauh lebih baik dibanding kehidupan dunia, maka minimal ada dua hal yang bisa dilakukan :

1) Taqlid (bukan pengetahuan), yaitu dia tahu dan paham bahwasanya kehidupan akhirat jauh lebih baik dibanding kehidupan dunia, kemudian dia mengamini dan membenarkannya dengan tidak melihat lebih detail lagi hakikat kehidupan akhirat. Dalam hal ini berarti dia cuma berpatokan kepada ucapan orang lain dalam melakukan rangkaian ibadah akhirat.

2) Tafakkur, yaitu dia tahu dan paham bahwasanya akhirat yang kekal jauh lebih baik dari dunia dan seisinya itu berasal dari inisiatif dirinya. Dalam hal ini berarti dia meraih dua macam ma'rifat. Kehadiran dua mmacam ma'rifat inilah dia bisa sampai kepada ma'rifat yang ke tiga yang disebut dengan tafakkur. ${ }^{8}$

Sebagian ulama ada yang mengartikan kata tafakkur dengan keadaan qalbu yang selalu mengingat Allah. Maksunya adalah seorang insan yang senantiasa merenungkan rahasia dari berbagai benda yang diciptakan oleh Allah SWT sampai benda-benda terkecil sehingga menyerupai sebuah cermin yang diletakkan di depan alam ghaib. Ketika hamba Allah itu melihat semua ciptaan dengan mata hatinya, maka cahaya penglihatannya mampu menembus hakikat alam.

Dalam bahasa Indonesia, makna dari kata tafakkur adalah suatu tindakan yang menampakan sikap perenungan, pemikiran, dan penimbangan yang dilakukan dengan penuh kesungguhan. ${ }^{9}$ Pada hakikatnya, tafakkur merupakan suatu kesadaran untuk mendapatkan bukti adanya Allah dan kekuasaan-Nya yang bermuara ujungnya pada suatu keyakinan. Pada tahap berikutnya aktifitas tafakkur ini membuat manusia bisa memposisikan dirinya di alam semesta yang luas dengan mengetahui keadaan bagus dan buruk hanya bermodalkan kekuatan akal sehat dan iman yang kuat. Hal itu akan membantunya untuk bisa menerima kebaikan yang melahirkan ketenangan

\footnotetext{
${ }^{7}$ Al-Ghazali, Ihya' Ulum al-Din, (Cairo : Maktabah Mishr, 1998), hlm. 504 hlm. 35

${ }^{8}$ BadriMalik,Tafakur : Perspektif Psikologi Islami (terjemahan),(Bandung : Rosdakarya, 1989), ${ }^{9}$ http;//Bahasa. Cs. Ui. Ac. Id/kbbi.php/tafakur/(diakses tanggal 25 Oktober 2013)
} 
qalbu. Dua unsur penting ini (iman dan akal) juga yang menolak keburukan atau perbuatan yang dibenci. Inilah merupakan inti dari ajaran Islam.

Berdasarkan definisi tafakkur seperti yang sudah dijelaskan di atas, bisa ditarik sebuah konklusi bahwasanya tafakkur adalah aktifitas befikir yang dilakukan secara mendalam sembari merenungkan semua ciptaan Allah yang ada di alam semesta (di langit dan di bumi) sebagai bukti kemahakuasaan-Nya dan kemahabesaran-Nya, serta meyakini bahwa kehidupan akhirat itu jauh lebih baik dan utama dibandingkan kehidupan dunia.

\section{Term al-Qur'an Tentang Tafakkur dan Term Semakna}

Al-Qur'an membicarakan masalah tafakkur dengan menggunakan term al-tafakkur secara langsung beserta beberapa bentuk kata yang memiliki akar yang sama dengannya. Di samping istilah al-tafakkur, ada dua term lain dalam kitab suci al-Qur'an yang mempunyai beberapa kesamaan maksud dan arti dengannya, yaitu al-ta'ammul dan altadabbur. Untuk membentuk pemahaman yang lebih komprehensif tentang tafakkur, maka ketiga istilah tadi perlu dibahas secara mendalam. Dengan demkian, akan didapatkan perspektif al-Qur'an yang orisinal tentang persoalan ini.

\section{Al-Tafakkur}

Al-Tafakkur adalah salah satu term yang digunakan oleh Allah di dalam kitab suci al-Qur'an. Pada umumnya kata ini terletak di akhir ayat dan digunakan tatkala alQur'an berbincang tentang semua ciptaan Allah, baik itu langit, bumi, burung, air, umat terdahulu, dan lain sebagainya. Kemudian Allah tutup ayat tersebut dengan kata al-tafakkur berikut dengan beberapa derivasinya, yang tujuannya supaya manusia mentafakkuri semua itu.

Al-Qur'an cukup reaktif dalam membicarakan masalah al-tafakkur ini. Secara eksplisit, paling tidak al-Qur'an menyediakan 17 ayatdalam 12 surat yang menggunakan term al-tafakkur dan segala bentuk kata jadiannya untuk membicarakan masalah ini. Ayat-ayat dimaksud adalah Q.S. Saba' : 46, al-Baqarah : 219 dan 266, al-An'am : 50, al-A'raf : 176 dan 184, al-Rum : 8 dan 21, Ali Imran : 191, Yujus : 24, al-Ra'du : 3, al-Nahal : 11, 44 dan 69, al-Zumar : 42, al-Jasiyah : 13, dan al-Hasyar : 21. ${ }^{10}$

\footnotetext{
${ }^{10}$ Muhammad Fuad Abdul Baqi, al-Mu'jam al-Mufahras li al-Fazh al-Qur'an, (Cairo : Dar al-Kutub al-Mishriyyah, 1364 H), h. 525
} 
Sementara secara implisit, term al-tafakkur bisa ditemukan dalam banyak ayat yang terdapat dalam 38 surat, yaitu Q.S. al-Baqarah, Ali Imran, al-An'am, al-A'raf, Yunus, al-Ra'du, al-Nahal, al-Hajj, al-Mu'minun, al-Nur, al-Furqan, al-Syu'ara', alQashas, al-Ankabut, al-Rum, Luqman, al-Sajadah, Saba', Yasin, Shaad, al-Zumar, Ghafir, al-Zukhruf, al-Dukhan, al-Jasiyah, Qaf, al-Zariyat, al-Waqi'ah, al-Hadid, alHasyar, al-Muluk, al-Haqqh, Nuh, al-Muddassir, al-Naba', Abasa, al-Thariq, alGhasyiyah dan al-Fajar. ${ }^{11}$

Ayat-ayat tersebut membicarkan dengan memadai tentang berbagai hal yang terkait dengan al-tafakkur. Jika ditelusuri dan ditafakkuri secara mendalam, maka akan ditemui bahwa pada ayat-ayat tersebut dibicarakan tentang objek tafakkur, urgensi, manfaat danbatasannya. Semua hal ini akan dibahas secara rinci dan detail pada pembahasan selanjutnya tentang spesifikasi elemen pokok al-tafakkur.

\section{Al-Ta'ammul}

Secara etimologi, al-ta'ammul (التأمل) merupakan bentuk mashdar dari fi'il تأمل) يتأمل , terambil dari madah (أمل) yang memiliki dua arti : Tetap dan menunggu dan berhenti memanah. ${ }^{12}$ Ahmad Warson Munawwir menulis dalam karyanya bahwa kata al-ta'ammul juga bermakna memikirkan dan merenungkan ${ }^{13}$ yang dalam bahasa Inggris diartikan dengan kata meditation. ${ }^{14}$ Secara kasat mata maknanya persis sama dengan kata al-Tafakkur. Adapun makna terminologi dari kata al-ta'ammul adalah :

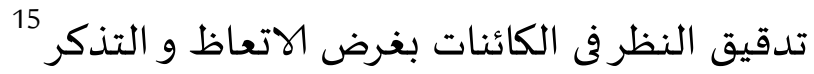

"Memperhatikan atau mengamati peristiwa-peristiwa yang terjadi di alam semesta dengan serius lagi mendalam serta kontiniu agar bisa diambil hikmahnya"

Salah satu term yang memiliki banyak kesamaan makna dengan al-tafakkur adalah al-ta'ammul.Walaupun lafaz al-ta'ammul tidak terdapat di dalam kitab suci al-Qur'an secara eksplisit dan juga tidak bisa dilihat secara kasat mata. Akan tetapi, jika diperhatikan dan diamati secara mendalam, maka akan ditemukan ayat-ayat al-

\footnotetext{
${ }^{11}$ Shubhi Abu al-Rauf, al-Mu'jam al-Maudhu'i li Ayat al-Qur'an al-Karim, (Cairo : Dar alFadhilah, 1990), hlm. 230-245.

${ }^{12}$ Ahmad bin Faris, Maqayis al-Lughah, (Cairo : Dar al-Sya'b, 1969), hlm. 140.

${ }^{13}$ Ahmad Warson Munawwir, Kamus al-Munawwir Arab-Indonesia Terlengkap, (Surabaya : Pustaka Progressif, 2003), hlm. 39.

${ }^{14}$ Oxford University Press, Oxford Wordpower, (London : Oxford University Press, 2006), hlm. 485.

${ }^{15} \mathrm{Abu}$ al-Baqa' al-Kafawi, al-Kulliyat Mu'jam al-Mushthalahat wa al-Furuq al-Lughawiyyah, (Beirut : Muassasah al-Risalah, 1993), hlm. 60.
} 
Qur'an yang sangat banyak yang mengajak manusia untuk memperhatikan ciptaan Allah, fenomena-fenomena yang terjadi alam, dan sejarah umat terdahulu.

Dalam kitab Nadhratu al-Na'im dijelaskan bahwa ada 34 ayat al-Qur'an yang secara makna (implisit) menyinggung term al-ta'ammul ini berikut objek yang harus dita'ammuli. ${ }^{16}$ Hal-hal yang harus dijadikan objek perhatian (al-ta'ammul) sebagaimana yang diperintahkan kitab suci al-Qur'an adalah sebagai berikut :

1) Al-Ta'ammul tentang penciptaan langit dan bumi \{Qs. al-Baqarah : 164, Ali Imran : 190, Yunus : 101, al-Isra' : 99, al-Anbiya' 30, al-Namal : 60, Luqman : 10-11 dan 20, dan al-Ahqaf : 33$\}$.

2) Al-Ta'ammul tentang air yang membasahi dan menghidupkan tumbuh-tumbuhan di bumi \{Qs. al-Baqarah : 164, Ali Imran : 190, Yunus : 101, dan al-Isra' : 199\}.

3) Al-Ta'ammul tentang umat terdahulu \{Qs. al-Anbiya' : 30, al-Namal : 60, Luqman : 10-11, Thaha : 128, al-Rum : 9, al-Sajadah : 26, Fathir : 44, dan Ghafir : 21 dan 28$\}$.

4) Al-Ta'ammul tentang penciptaan manusia \{Qs. al-Hajj : 5, al-Ankabut : 19-20, dan Yasin : 77\}.

5) Al-Ta'ammul tentang penciptaan burung \{Qs. al-Muluk : 19\}.

6) Al-Ta'ammul tentang nikmat Allah dan keajaiban makhluknya \{Qs. al-Nkabut : 67, Luqman : 29 dan 31, Saba' : 9, al-Jasiah : 3-5, Qaf : 5-11, al-Waqi'ah : 58-74, dan al-Ghasiah : 17-21\}. ${ }^{17}$

\section{Al-Tadabbur}

Term lain yang digunakan oleh Allah untuk menyebut usaha berfikir adalah altadabbur. Jika diperhatikan teks-teks al-Qur'an, akan didapatkan istilah ini dengan beberapa bentuk derivasinya sebanyak 4 kali, dan itu terdapat pada empat buah ayat saja. Ayat dan kata-kata tersebut adalah Q.S. al-Nisa' : 82, al-Mu'minun : 68, Shaad : 29, dan Muhammad : 24. ${ }^{18}$ Menurut bahasa atau etimologi, kata al-tadabbur (التدبر) adalah masdar dari kata tadabbara (تدبر) yang terambil dari madah $(د){ }^{19}$ yang

\footnotetext{
${ }^{16}$ Shalih bin Abdillah bin Humaid, dkk, Mausu'ah Nadhrah al-Na'im fi Makarim Akhlaq al-Rasul al-Karim, (Jeddah : Dar al-Wasilah, 2006), hlm. 843.

${ }^{17}$ Ibid., hlm. 849-852.

${ }^{18}$ Ibid., hlm. 911.

${ }^{19}$ Ibnu Faris, hlm. 324.
} 


\section{--Jurnal El-Qanuny}

---Volume 5 Nomor 1 Edisi Januari - Juni 2019

artinya menurut Ibnu Manzhur adalah melihat akibat akhir segala urusan. ${ }^{20}$ Makna terminologi dari al-tadabbur menurut ahli bahasa Arab, seperti al-Jurjani adalah :

$$
\text { تصرفه بالنظر في العواقب النور وهو قريب من التفكر إلا أن التفكر تصرف القلب بالنظرفى الدليل و التدبر }
$$

"Melihat dan memperhatikan akibat, dampak, atau efek akhir dari segala sesuatu. Artinya tidak jauh berbeda dengan makna tafakkur. Titik perbedaannya terdapat pada bahwa tafakkur itu memakai mata hati guna melakuakan penelitian terhadap dalil atau indikator dari suatu hal. Sementara tadabbur memanfaatkan mata hati guna mencerna akibat-akibat akhir dari suatu hal."

\section{Pelacakan Ayat-Ayat Tafakkur dalam Al-Qur'an}

Pada pembahasan sebelumnya sudah dipaparkan secara global jumlah ayat-ayat tentang al-tafakkur di dalam al-Qur'an.Untuk membentuk pemahaman yang lebih komprehensif tentang al-tafakkur, ada baiknya dikemukakan semua ayat-ayat tersebut. Ayat-ayatnya sebagai berikut :

1. Qs. al-Baqarah : 219.

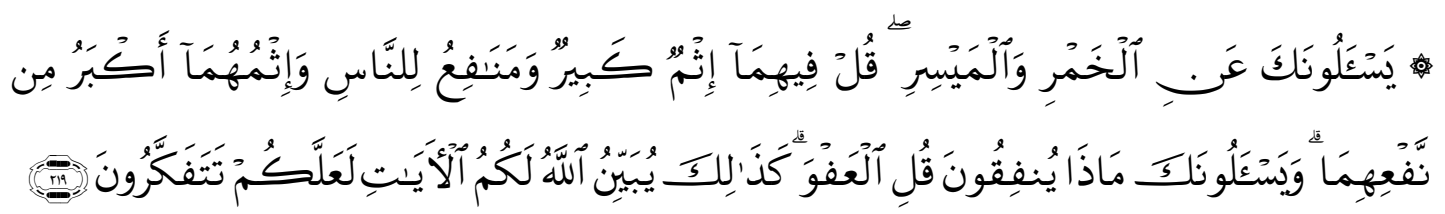

2. Qs. al-Baqarah : 266.

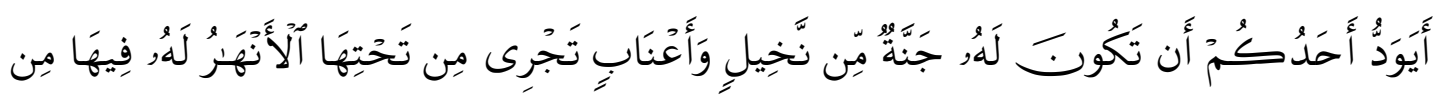

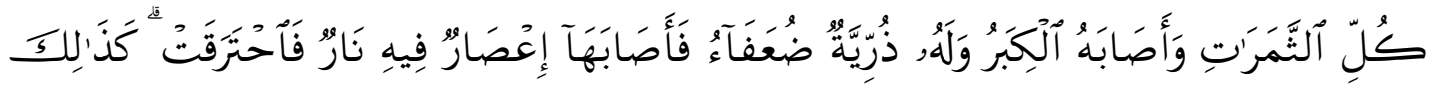

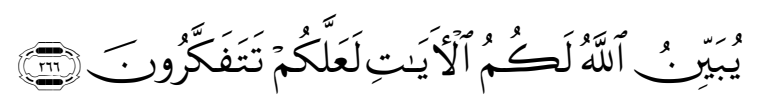

3. Qs. Ali Imran : 190-192.

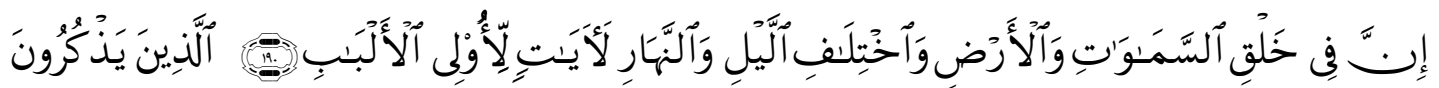

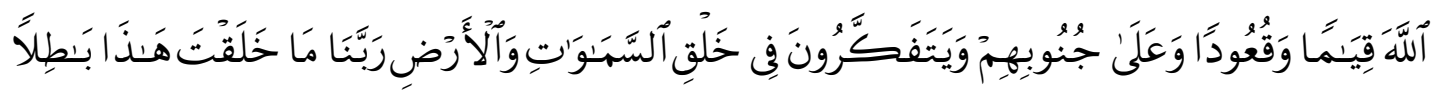

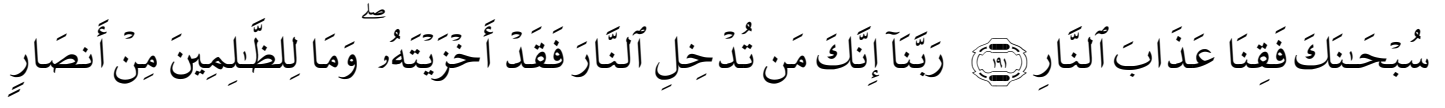

4. Qs. al-An'am : 50.

\footnotetext{
${ }^{20}$ Ibnu Manzhur, Lisan al-Arab, (Beirut : Dar al-Shadir, 196), hlm. 273.

${ }^{21}$ Al-Jurjani, hlm. 54
} 


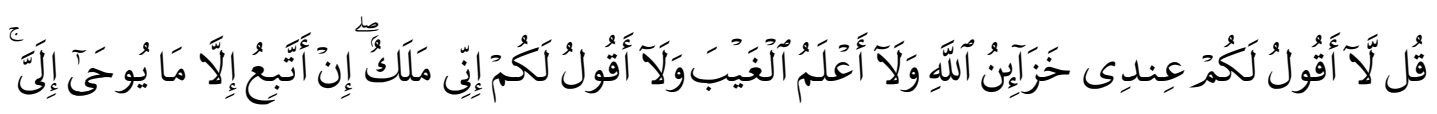

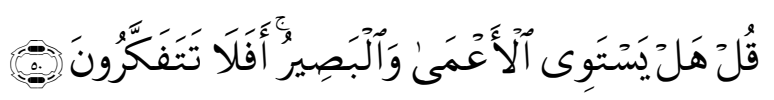

5. Q.S. al-A'raf :175-176.

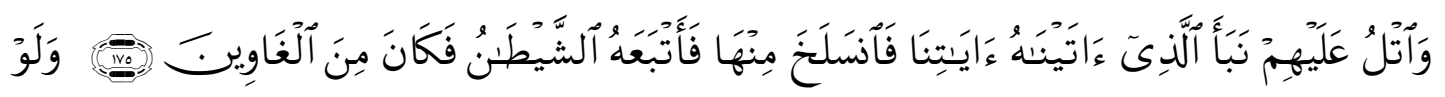

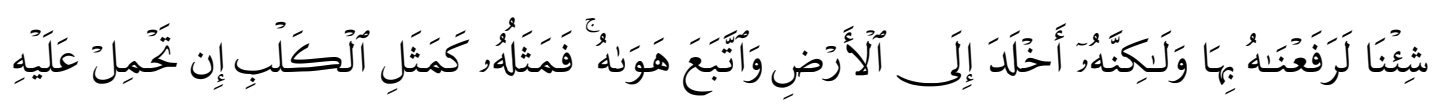

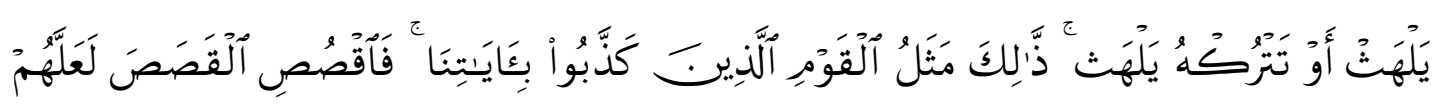
يَتَفَكَرُونَ

6. Qs. al-A'raf :184-185.

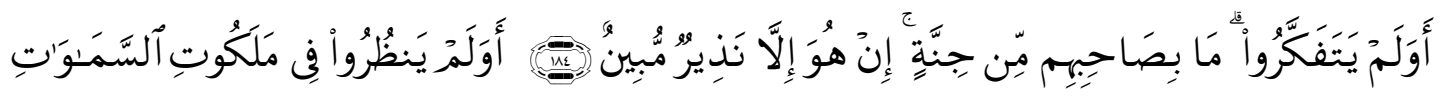

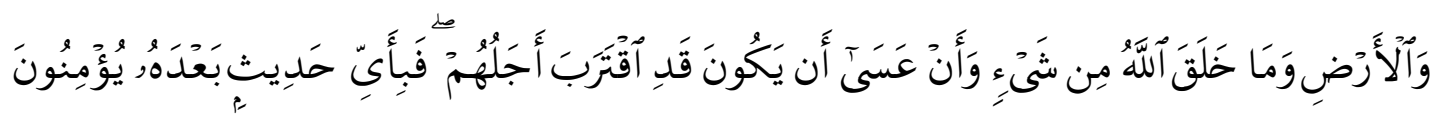

7. Qs. Yunus : 24.

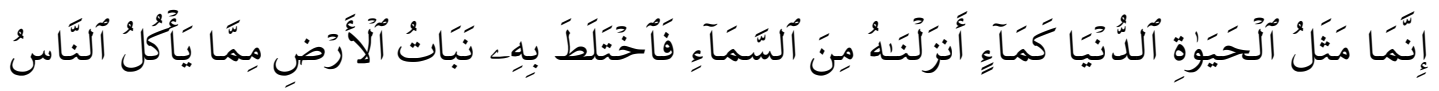

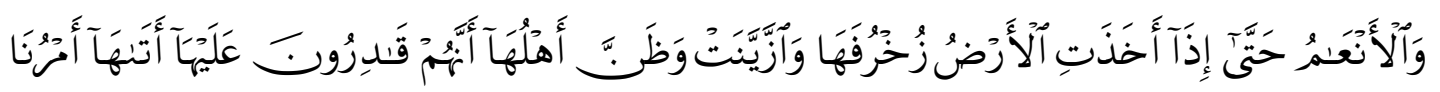

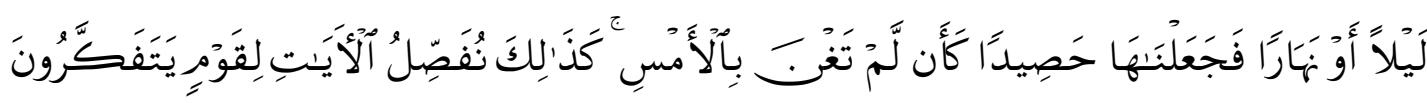

8. Qs. al-Ra'd : 2-3.

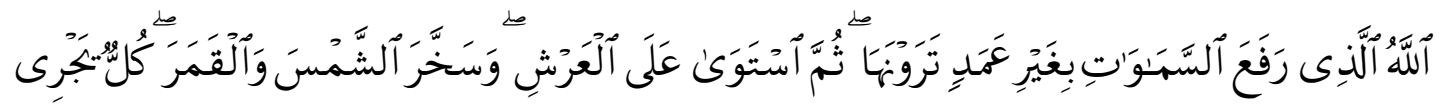

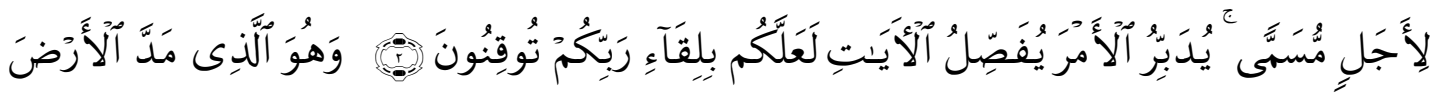

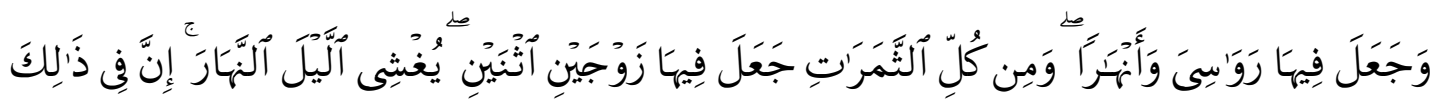

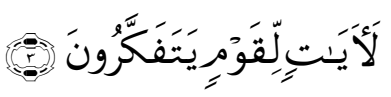

9. Qs. al-Nahal : 10-11. 


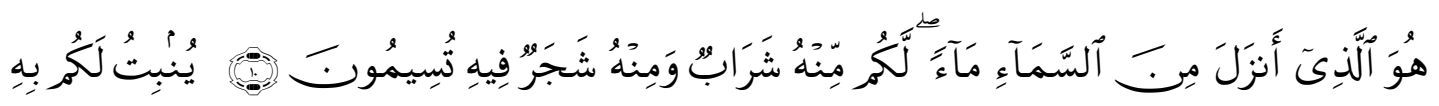

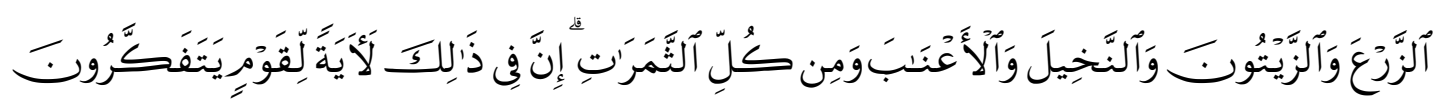

10. Qs. al-Nahal : 43-44.

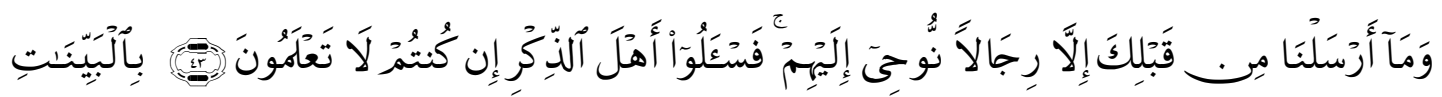

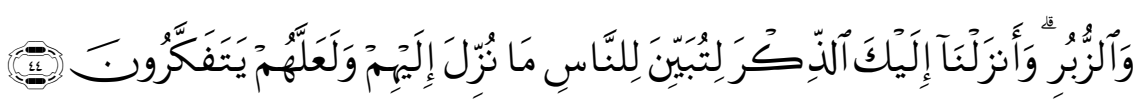

11. Qs. al-Nahal : 68-69.

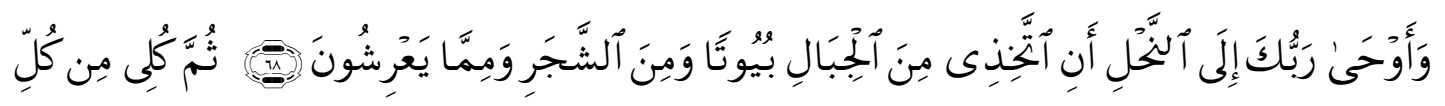

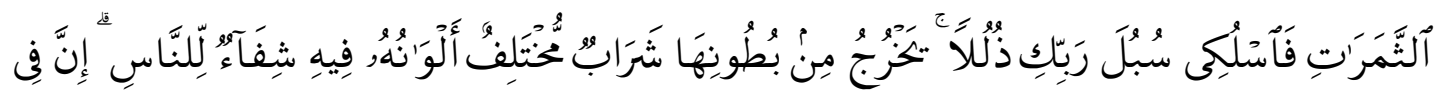

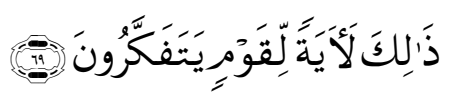

12. Qs. al-Rum : 8.

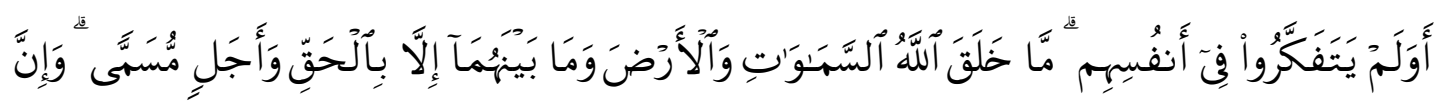

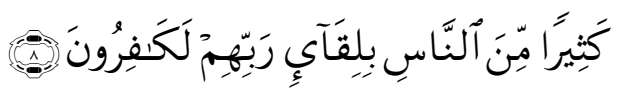

13. Qs. al-Rum : 20-21.

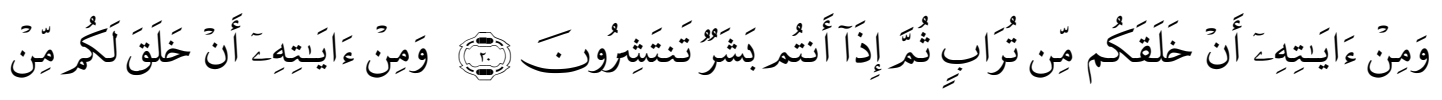

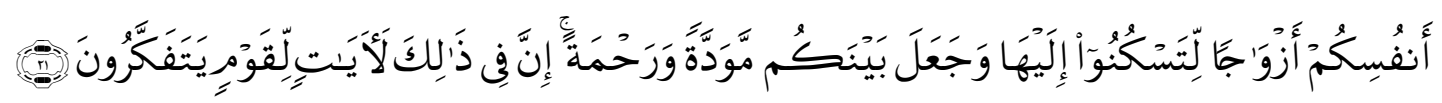

14. Qs. Saba' : 46.

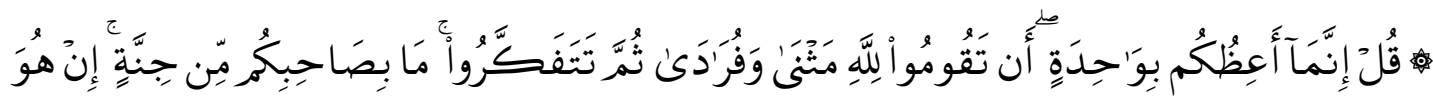

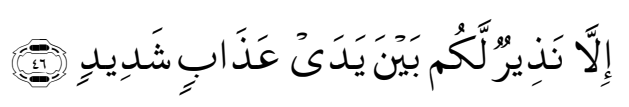

15. Qs. al-Zumar : 42.

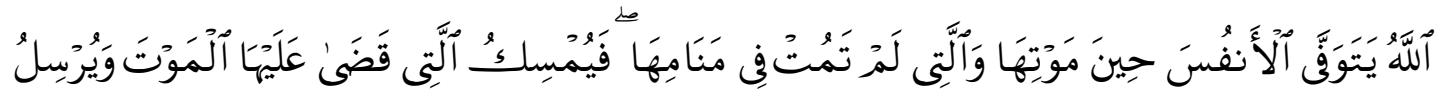

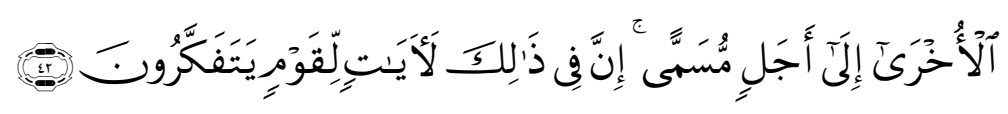

16. Qs. al-Jasiyah : 12-13. 


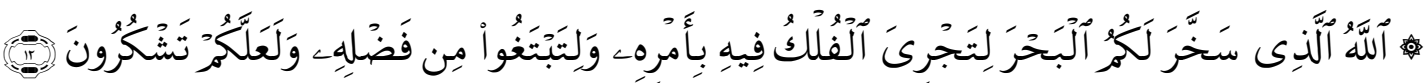

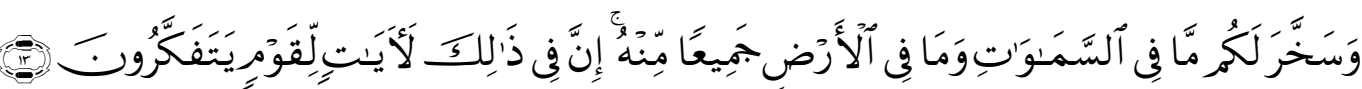

17. Qs. al-Hasyar : 20-21.

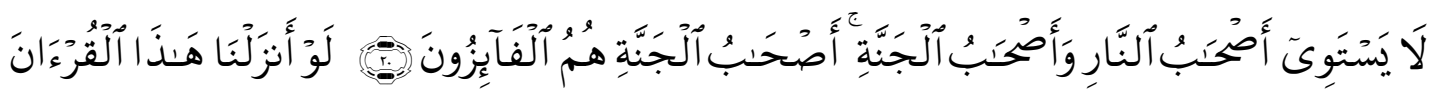

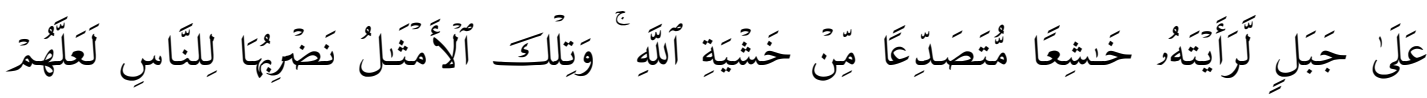

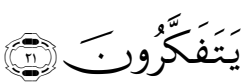

\section{E. Spesifikasi Elemen Pokok Tafakkur}

Dari penelusuran nash-nash al-Qur'an tentang tafakkur tersebut, bisa dibahas beberapa klasifikasi atau spesifikasi elemen pokok tafakkur sebagai berikut :

1. Objek Tafakkur

Secara umum, objek tafakur sebagaimana yang bisa dilihat dari ayat-ayat sebelumnya adalah suatu aktifitas berfikir dan merenung terhadap ciptaan atau makhluk Allah SWT. Dalam hal ini bisa diambil beberapa contoh ayat :

a. Qs. Ali Imran : 190-192.

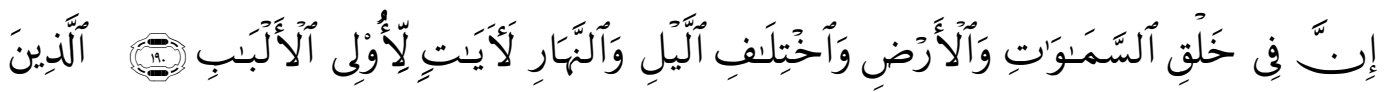

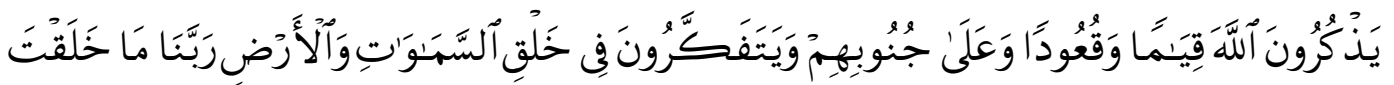

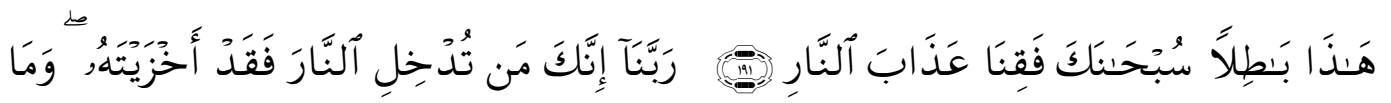

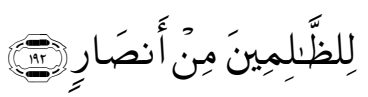

b. Qs. al-Ra'd : 2-3.

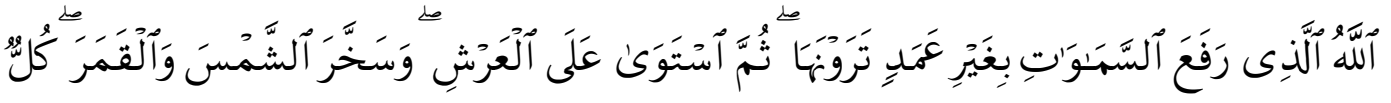

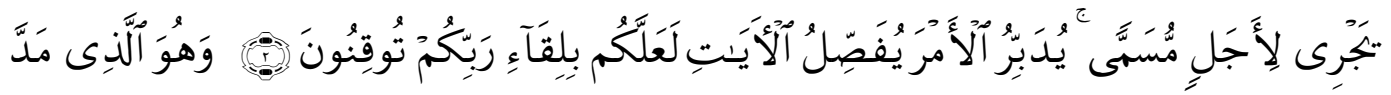

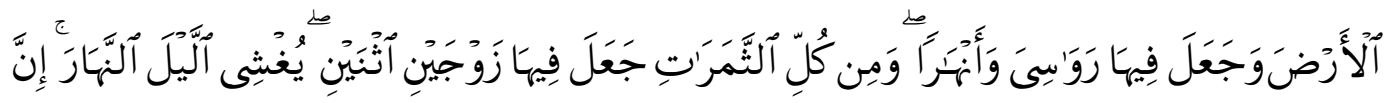

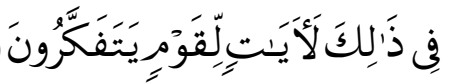


Berkaitan dengan ayat ini, Imam Sya'rawi memberi komentar dalam kitabnya bahwa manusia memiliki tanggung jawab untuk mentafakkuri alam sekitarnya atau jagad raya ini agar bisa sampai kepada kebenaran sejati. ${ }^{22}$ Melakukan perenungan terhadap gejala alam yang terjadi di semesta akan memberikan manfaat yang sangat besar dalam rangka menyingkap segala tanda-tanda kebesaran dan kekuasaan Allah SWT yang akan mengantarkan manusia menjadi makhluk yang selalu patuh, tunduk, dan taat kepada sang Pencipta, yaitu Allah SWT. Namun, ada batasan penting yang tidak boleh dilewati dan wajib diperhatikan ketika mau bertafakkur, yaitu kita tidak boleh memikirkan, merenungkan atau mentafakkuri sesuatu yang berkaitan dengan Zat Allah SWT.

Dalam sebuah riwiyat diceritakan bahwa suatu kali ada seseorang mengajukan sebua pertanyaan kepada Imam Malik bin Anas. Pertanyaannya tentang cara bersemayamnya Allah (istawa) di atas arsyi-Nya. Sang imam pun termenung dan berfikir sejenak, kemudian menjawab dengan bijak :

$$
\text { الإستواء معلوم والكيف غير معلوم والإيمان به واجب والسؤال عنه بدعة }
$$

"Istiwa' itu telah diketahui maknanya, tetapi bagaimana caranya tidak diketahui, mengimaninya adalah wajib, dan bertanya tentangnya adalah bid'ah."

Tidak disangka ternyata jawaban yang dicetuskan oleh Imam Malik ini jadi kaidah yang terkenal pada masa sesudahnya di kalangan para ulama ketika menyikapi persoalan yang berkaitan dengan zat atau sifat Allah SWT. Oleh karena itu, seorang muslim dilarang untuk bertafakkur atau memikirkan tentang zat atau sifat Allah SWT. Sikap yang bijak dan penuh hikmah yang patut dilakukan terkait dalil-dalil yang menjelaskan tentang zat atau sifat Allah adalah meyakininya dengan sepenuh hati tanpa melakukan empat hal yang dilarang, yaitu : 1) Takwil : tafsir, 2) Takyif (bertanya tentang caranya), 3) ta'thil (menolak sebagian atau seluruhnya), dan 4) tamtsil (menyetarakannya dengan zat atau sifat makhluk). Jika hal ini dilakukan, maka akan selamat dari kesalahan.

\section{Urgensi Tafakkur}

Jika manusia tidak suka mentafakkuri fenomena-fenomena yang terjadi di alam semesta yang sudah diciptakan oleh Allah, maka dia akan susah untuk menjadi

\footnotetext{
${ }^{22} \mathrm{Al}$-Sya'rawi, Tafsir al-Sya'rawi, (Cairo : Majamma' al-Buhus al-Islamiyyah, tt), hlm. 7198.
} 
hamba yang bersyukur kepada Pencipta jagad raya ini. Sebab, pada saat itu qalbu dan sanubarinya sudah dipenuhi oleh kegelapan, noda dan dosa yang akan mengantarnya menjadi insan yang takabbur dan kufur terhadap nikmat yang telah dianugerhkan Allah. Akibat akhir dari kekufuran ini adalah dia akan merasakan adzab Allah. Disinyalir dalam al-Qur'an bahwa sudah banyak negeri hancur lebur akibat dari perbuatan manusia atau penghuni negeri itu tidak pandai mensyukuri nikmat Tuhan. Terkait pentingnya al-tafakkur, supaya manusia bisa bersyukur ini bisa dilihat dalam firman Allah, Q.S. al-Jasiyah : 12-13.

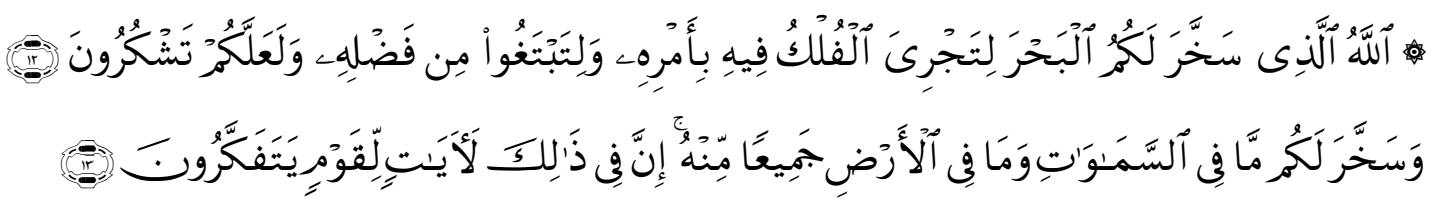

\section{Manfaat Tafakkur}

Adapun manfaat yang dapat diambil dari tafakkur adalah sebagai berikut :

a) Tafakkur menjadi tanda bagi orang yang memanfaatkan fikirannya yang dalam bahasa al-Qur'an dikenal dengan istilah ulul albab. Faidah ini menurut Imam Thabari terinspirasi dari Qs. al-Ra'du : 2-3, bahwa semua keajaiban dan keagungan ciptaan Allah itu adalah sebagai ayat atau tanda bagi orang-orang yang bertafakkur. ${ }^{23}$

b) Tafakkur bisa menghapus sikap lalai dalam berubudiah kepada Allah sekaligus bisa menghadirkan rasa takut yang besar di dalam hati kepada sang Khalik. Ibarat tanaman yang akan tumbuh subur karena adanya siraman air yang teratur. \{Qs. al-Nahal : 10-11\}.

c) Tafakkur itu bagaikan sebuah cermin. Di cermin itu akan nampak kebaikan dan keburukan orang yang ada di depannya. Pancaran cermin yang nampak itu merupakan perilaku baik atau buruknya. \{Qs. al-Rum : 8-9\}.

d) Tafakkur merupakan sebuah cahaya, sementara hati yang lalai merupakan kegelapan dan kejahilan. \{Qs. Saba' : 46\}.

e) Tafakkur bisa menambah mahabbah kepada Zat yang memberikan rasa cinta dan bisa menjadikan hamba yang pandai mensyukuri nikmat-nikmat sang Pemberi nikmat. \{Qs. al-Nahal 10-14\}.

\footnotetext{
${ }^{23}$ Al-Thabari, Jami'u al-Bayan an Ta'wil al-Qur'an, (Cairo : Maktabah Ibnu al-Taimiyyah, tt), hlm.
} 
f) Bisa menambah semangat dalam melakukan ibada dan kebaikan lainnya serta bisa lebih siap untuk menghadapi yaumul hisab di akhirat kelak.

g) Bisa menumbuhkan dan menambah rasa takut terhadap adzab yang akan diberikan Allah, sehingga diri terhindar dari perbuatan noda, dosa, segala macam maksiat. \{Qs. al-Baqarah : 266\}.

h) Bisa menguatkan frekuensi keimanan dan meningkatkan ketaatannya sehingga cita-cita menggapai surge bisa terwujud. \{Qs. al-Baqarah : 266\}.

i) Bisa mendatangkan rasa malu ketika diri ingin melakukan dosa dan maksiat dan sanggup untuk menghindarkan diri dari perbuatan yang tidak terpuji.

Inilah di antara manfaat yang bisa diraih bagi orang yang mau menggunakan fikirannya dengan melakukan tafakkur dan tadabbur atas semua ciptaan Pencipta alam semesta. Minimal bisa melakukan tafakkur mulai dari yang terkecil atau yang terdekat, yaitu diri pribadinya yang sudah diciptakan dengan sempurna. ${ }^{24}$

\section{Batasan Tafakkur}

Manusia memang diperintahkan untuk bertafakkur oleh Allah SWT.Akan tetapi, segala sesuatu itu tentu ada batasnya dan tidak semua hal bisa difikirkan oleh manusia.Oleh karena itu, dalam bertafakkur pun ada aturannya. Di antara batasan tafakkur yang bisa disimpulkan dari semua ayat-ayat tentang tafakkur adalah :

a. Tidak boleh bertafakkur jika mendatangkan mudharat terhadap diri.

b. Tidak boleh bertaffakur mengenai zat / bentuk / jisim Allah.

c. Bertafakkur hendaknya menjadikan kita semakin yakin pada Allah. Jangan sampai sebaliknya membuat kita ragu kepada Tuhan pencipta langit dan bumi ini.

\section{F. Penutup}

Dari pemaparan sebelumnya bisa ditarik beberapa konklusi sebagai berikut :

1. Al-tafakkur adalah befikir secara mendalam dan merenungi segala ciptaan Allah sebagai bukti kemahabesaran-Nya dan menganggap bahwa akhirat lebih utama dari pada dunia.

2. Secara eksplisit, paling tidak al-Qur'an menyediakan 17 ayat dalam 12 surat yang menggunakan term al-tafakkur dan segala bentuk kata jadiannya. Sementara secara

\footnotetext{
${ }^{24}$ http://Arenasahabat.blogspot.com/.../urgensi-faedah-tafakkur-dan-tadabbur/ (Diakses tanggal 25 Oktober 2013)
} 
implisit, term al-tafakkur bisa ditemukan dalam banyak ayat yang terdapat dalam 38surat.

3. Di samping istilah al-tafakkur, ada dua nama lain dalam al-Qur'an yang memiliki beberapa kesamaan arti dengannya, yaitu al-ta'ammul dan al-tadabbur.

4. Secara umum, objek tafakur adalah memikirkan dan merenungkan makhluk Allah SWT. Termasuk dalam kategori makhluk Allah adalah alam semesta beserta segala yang dikandungnya.

5. Sebagai seorang Muslim, tafakkur sangat penting dilakukan supaya bisa menjadi hamba yang bersyukur.

6. Al-Tafakkur sangat banyak sekali manfaatnya jika dilakukan sesuai dengan benar.

7. Al-Tafakkur ada batasannya. Di antaranya, tidak boleh bertafakkur mengenai zat Allah, tidak mendatangkan mudharat, dan al-tafaakkur harus menjadikan kita semakin yakin kepada Allah.

\section{DAFTAR PUSTAKA}

Al-Ghazali, Ihya' Ulum al-Din,Cairo : Maktabah Mishr, 1998.

Ali, Atabik, dkk, Kamus Kontemporer Arab Indonesia,Yokyakarta : Multi Karya Grafika, 1998.

Al-Jauziyah, Ibnu al-Qayyim, al-Fawa'id ,Cairo : Dar al-Rayyan Li al-Turas, 1987.

Al-Jurjani, al-Ta'rifat, Beirut : Dar al-Kutub al-Ilmiyyah, $1403 \mathrm{H}$.

Al-Kafawi, Abu al-Baqa', al-Kulliyat Mu'jam al-Mushthalahat wa al-Furuq alLughawiyyah,Beirut : Muassasah al-Risalah, 1993.

Al-Rauf, Shubhi Abu, al-Mu'jam al-Maudhu'i li Ayat al-Qur'an al-Karim,Cairo : Dar alFadhilah, 1990.

Al-Sya'rawi, Tafsir al-Sya'rawi,Cairo : Majamma' al-Buhus al-Islamiyyah, tt.

Al-Thabari, Jami'u al-Bayan an Ta'wil al-Qur'an,Cairo : Maktabah Ibnu al-Taimiyyah, tt.

Baqi, Muhammad Fuad Abdul, al-Mu'jam al-Mufahras li al-Fazh al-Qur'an,Cairo : Dar al-Kutub al-Mishriyyah, $1364 \mathrm{H}$.

Gunawan, Hendra,. Karakteristik Hukum Islam, Jurnal Al-Maqasid; Jurnal Ilmu Kesyariahan dan Keperdataan Fakultas Syariah dan Ilmu Hukum IAIN Padangsidimpuan, Vol. 4 No. 2. Edisi Juli-Desember 2018.

http;//Arenasahabat.blogspot.com/.../urgensi-faedah-tafakkur-dan-tadabbur/(Diakses tanggal 25 Oktober 2013).

http;//Bahasa. Cs. Ui. Ac. Id/kbbi.php/tafakur/(Diakses tangggal 25 Oktober 2013).

Ibnu Faris, Ahmad, Maqayis al-Lughah, Cairo : Dar al-Sya'b, 1969. 
Ibnu Humaid, Shalih bin Abdillah, dkk, Mausu'ah Nadhrah al-Na'im fi Makarim Akhlaq al-Rasul al-Karim,Jeddah : Dar al-Wasilah, 2006.

Ibnu Manzhur, Lisan al-Arab,Beirut : Dar al-Shadir, 196.

Majamma' al-Lughah al-Arabiyah, al-Mu'jam al-Wasith, Cairo : Maktabah al-Syuruq alArabiyyah, 2005.

Malik, Badri, Tafakur : Perspektif Psikologi Islami (terjemahan), Bandung : Rosdakarya, 1989.

Munawwir, Ahmad Warson, Kamus al-Munawwir Arab-Indonesia Terlengkap, Surabaya : Pustaka Progressif, 2003.

Oxford University Press, Oxford Wordpower,London : Oxford University Press, 2006.

S. Wojowasito, dkk, Kamus Lengkap Inggris Indonesia-Indonesia Inggris, Bandung : HASTA Penerbit, 1983.

Saleh, Abdul Rahman, Psikologi Suatu Pengantar dalam Perspektif Islam,Jakarta : Kencana Media Group, 2005.

Yunus, Mahmud, Kamus Arab Indonesia, Jakarta : PT. Mahmud Yunus Wa Dzurriyyah, 2010. 